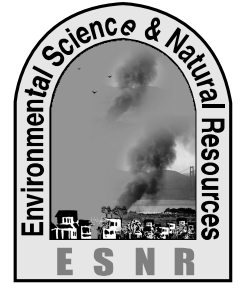

\title{
Response of Nitrogen Application at Different Growth Stages on Fine Aman Rice (CV. Kalizira)
}

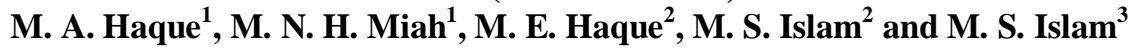 \\ ${ }^{1}$ Department of Agriculture Chemistry, BAU, Mymensingh \\ ${ }^{2} \mathrm{UAO}, \mathrm{DAE}$ and ${ }^{3} \mathrm{PO}$, RKU Bank, Natore
}

\begin{abstract}
An experiment was conducted at the Agronomy Farm, Bangladesh Agricultural University during the aman season of 2005-2006 to investigate the response of different doses of nitrogen application at different growth stages on fine aman rice (cv. kalizira). The experiment consisted of 3 levels of $\mathrm{N}$ application namely, $50 \%$ of recommended $\mathrm{N}, 100 \%$ of recommended $\mathrm{N}\left(150 \mathrm{~kg} \mathrm{ha}{ }^{-1}\right)$ and $25 \%$ higher than recommended $\mathrm{N}$ and 3 different plant growth stages of $\mathrm{N}$ application namely transplanting, maximum tillering and panicle initiation stage. The application of single super phosphate, muriate of potash, gypsum and zinc sulphate were same in all the plots at the rate of $125,67,20$ and $5 \mathrm{~kg} \mathrm{ha}^{-1}$, respectively. The experiment was laid out in a split plot design (SPD) with three replications. All data were analyzed using the analysis of variance technique and the mean differences were adjusted by DMRT. The results revealed that different doses of nitrogen had significant positive effect on the most of the vegetative parameters. Plant height, numbers of tiller hill ${ }^{-1}$, leaf hill ${ }^{-1}$, dry matter hill ${ }^{-1}$ were to be highest with the increasing rate of nitrogen at all sampling excluding final harvest.
\end{abstract}

Key words: Agronomic practice,Growth stages, Kalizira variety, Nitrogen fertilizer

\section{Introduction}

Bangladesh is known to be highly vulnerable to floods and faced every year minor to major of its effect. Abnormal floods submerge about $60 \%$ of the land, damage crops, property; disrupt economic activities and cause diseases and loss of life (Nasreen, 2004). About $60 \%$ land of Bangladesh is flood-prone while $25 \%$ areas in Bangladesh are inundated by monsoon flood water between June and October every year (Uddin, 2004). BRRI (1981) also reported that about $30-40 \%$ area under transplant aman rice is planted late beyond optimum time due to delayed harvest aus rice and jute crop coupled with the associated turn-around time.

Aromatic rice is the most highly valued rice commodity in Bangladesh agricultural trade market having small grain, pleasant aroma with soft texture upon cooking (Dutta et al., 1998). Fine rice cultivar Kalizira can be transplanted late even up to last week of September, which keeps a high margin in comparison to local as well as the other indigenous transplant aman fine rice cultivars. But when transplanted late in September it has a poor opportunity to produce enough tillers before reaching its reproductive phase. Among different improved agronomic practices, rate and time of nitrogen application may compensate the yield loss of transplant aman rice due to late transplanting. BRRI (1990) reported that nitrogen has a positive influence on the production of effective tillers. But excess amount of nitrogen fertilizer results in lodging of plant, prolonging growing period, delaying maturity and reducing yield (Uddin,2003). Quite a large number of experiments have so far been carried out through out the world to find out the optimum level of nitrogen in rice. However, in the country sufficient research work have not yet been done on different level of nitrogenous fertilizer especially with late planted fine aman rice. The present piece of research work was, therefore, undertaken to find out the response of different doses of nitrogen application at different growth stages on fine aman rice (cv. kalizira).

\section{Materials and Methods}

The experiment was conducted at the Agricultural Farm, Bangladesh Agricultural University during the aman season of 2005-2006 to investigate the response of different doses of nitrogen application at different growth stages on fine aman rice (cv. kalizira). The experiment consisted of 3 levels of $\mathrm{N}$ application $\left(\mathrm{kg} \mathrm{ha}^{-1}\right)$ namely, $50 \%$ of recommended dose of $\mathrm{N}\left(\mathrm{N}_{1}\right), 100 \%$ of recommended dose of $\mathrm{N}$ $\left(\mathrm{N}_{2}\right)$ and $25 \%$ higher than recommended dose of $\mathrm{N}$ $\left(\mathrm{N}_{3}\right)$ and 3 different plant growth stages of $\mathrm{N}$ application namely transplanting $\left(\mathrm{T}_{1}\right)$, maximum tillering $\left(\mathrm{T}_{2}\right)$ and panicle initiation stage $\left(\mathrm{T}_{3}\right)$. According to the soil test values and their interpretations, the fertilizers dose were recommended with the help of FRG (2005) namely urea, single super phosphate, muriate of potash, gypsum and zinc sulphate at the rate of 150, 125, 67, 20 and $5 \mathrm{~kg} \mathrm{ha}^{-1}$ respectively and except urea entire fertilizers were applied as same in all the plots at the time of final land preparation. Urea was applied in three equal splits at transplanting, maximum tillering 
and panicle initiation stage of the crop. The experiment was laid out in a split plot design (SPD) with three replications. The unit plot size was $5 \mathrm{~m} \mathrm{x} 2$ $\mathrm{m}$ with an inter-plot and inter-block spacing of $0.5 \mathrm{~m}$ and $1.5 \mathrm{~m}$ respectively. Thirty days old two healthy seedlings were transplanted per hill in the experimental plots at a plant spacing of $20 \mathrm{~cm} \mathrm{x} 15$ $\mathrm{cm}$ on 16 September, 2005 and the crop was harvested at maturity on 7 January, 2006. All the intercultural practices such as gap filling, weeding, water and pest management were done in time as and when necessary. Five hills were randomly selected from each plot for data collection excluding border rows. The data recorded at vegetative stage continued at 15 day intervals beginning from 45 DAT up to 75 DAT and harvesting of the crop and the parameters were plant height $(\mathrm{cm})$, number of tillers hill ${ }^{-1}$, number of leaves hill ${ }^{-1}$, shoot dry matter gm hill ${ }^{-1}$. All data were analyzed using the analysis of variance technique and the mean differences among the treatment were adjusted by DMRT (Gomez and Gomez, 1984).

\section{Results and Discussions}

\section{Plant height}

Plant height was significantly affected by both the nitrogen application at different growth stage and the amount of nitrogen applied at all dates of sampling. At 45, 60 and 75 DAT, the tallest plant height was found $59.37,80.20$ and $102.63 \mathrm{~cm}$ when $\mathrm{N}$ was applied at transplanting, maximum tillering and panicle initiation stage respectively. At all the DAT (45, 60 and 75), the longest plant was found 62.62, 83.81 and $107.29 \mathrm{~cm}$ respectively in $25 \%$ higher $\mathrm{N}$ level than recommended dose (Table 1 ). The results indicated that plant height increased with higher level of $\mathrm{N}$ applied. The result is similar to the findings of Lawal and Lawal (2002) that plant height responded to $\mathrm{N}$ up to $120 \mathrm{~kg} \mathrm{~N} \mathrm{ha}^{-1}$.

Table 1. Effect of $\mathrm{N}$ application stage and $\mathrm{N}$ levels on different plant characters at different days after transplanting (DAT)

\begin{tabular}{|c|l|l|l|l|l|l|l|l|l|}
\hline \multirow{2}{*}{ Treatment } & \multicolumn{3}{|c|}{ Plant height (cm) } & \multicolumn{3}{c|}{ No. of total tiller hill ${ }^{-1}$} & \multicolumn{3}{c|}{ No. of leaf hill $^{-1}$} \\
\cline { 2 - 10 } & 45 DAT & 60 DAT & 75 DAT & 45 DAT & 60 DAT & 75 DAT & 45 DAT & 60 DAT & 75 DAT \\
\hline $\mathrm{T}_{1}$ & $59.37 \mathrm{a}$ & $78.05 \mathrm{ab}$ & $90.37 \mathrm{~b}$ & $14.85 \mathrm{a}$ & $10.42 \mathrm{~b}$ & $7.46 \mathrm{~b}$ & $83.65 \mathrm{a}$ & $57.38 \mathrm{ab}$ & $48.72 \mathrm{~b}$ \\
\hline $\mathrm{T}_{2}$ & $55.57 \mathrm{ab}$ & $80.20 \mathrm{a}$ & $97.77 \mathrm{ab}$ & $13.55 \mathrm{~b}$ & $11.82 \mathrm{a}$ & $8.18 \mathrm{ab}$ & $80.40 \mathrm{a}$ & $64.00 \mathrm{a}$ & $55.40 \mathrm{ab}$ \\
\hline $\mathrm{T}_{3}$ & $51.59 \mathrm{~b}$ & $75.35 \mathrm{~b}$ & $102.63 \mathrm{a}$ & $12.15 \mathrm{c}$ & $8.83 \mathrm{c}$ & $9.02 \mathrm{a}$ & $75.87 \mathrm{~b}$ & $54.71 \mathrm{~b}$ & $58.06 \mathrm{a}$ \\
\hline $\begin{array}{c}\text { Level of } \\
\text { significance }\end{array}$ & $* *$ & $* *$ & $* *$ & $* *$ & $* *$ & $* *$ & $* *$ & $* *$ & $* *$ \\
\hline $\mathrm{CV}(\%)$ & 6.32 & 4.54 & 6.49 & 5.24 & 7.15 & 7.78 & 3.20 & 6.46 & 7.64 \\
\hline $\mathrm{N}_{1}$ & $48.90 \mathrm{~b}$ & $72.46 \mathrm{~b}$ & $88.68 \mathrm{~b}$ & $11.83 \mathrm{c}$ & $8.61 \mathrm{~b}$ & $7.02 \mathrm{~b}$ & $77.44 \mathrm{~b}$ & $54.59 \mathrm{~b}$ & $42.60 \mathrm{c}$ \\
\hline $\mathrm{N}_{2}$ & $56.01 \mathrm{a}$ & $77.33 \mathrm{~b}$ & $94.79 \mathrm{~b}$ & $13.40 \mathrm{~b}$ & $10.58 \mathrm{a}$ & $8.27 \mathrm{a}$ & $80.36 \mathrm{ab}$ & $58.53 \mathrm{ab}$ & $55.03 \mathrm{~b}$ \\
\hline $\mathrm{N}_{3}$ & $62.62 \mathrm{a}$ & $83.81 \mathrm{a}$ & $107.29 \mathrm{a}$ & $15.31 \mathrm{a}$ & $11.88 \mathrm{a}$ & $9.37 \mathrm{a}$ & $82.12 \mathrm{a}$ & $62.98 \mathrm{a}$ & $64.55 \mathrm{a}$ \\
\hline $\begin{array}{c}\text { Level of } \\
\text { significance }\end{array}$ & $* *$ & $* *$ & $* *$ & $* *$ & $* *$ & $* *$ & $* *$ & $* *$ & $* *$ \\
\hline \begin{tabular}{c} 
CV(\%) \\
\hline
\end{tabular} & 6.32 & 4.54 & 6.49 & 5.24 & 7.15 & 7.78 & 3.20 & 6.46 & 7.64 \\
\hline
\end{tabular}

In a column figurers with same letter or with out letters do not differ significantly at the level of 5\% as per DMRT. $\quad \mathrm{NS}=$ Not significant,$\quad * *=1 \%$ level of significant.

$\mathrm{T}_{1}=$ Transplanting stage

$\mathrm{T}_{2}=$ Maximum tillering stage

$\mathrm{T}_{3}=$ Panicle initiation stage

Effect of interaction on nitrogen application at different growth stage and the amount of nitrogen applied was not significantly affected by plant height for all sampling except at 45 DAT. At 45 DAT, the tallest plant was observed $(64.95 \mathrm{~cm})$ when $100 \%$ of
$\mathrm{N}_{1}=50 \%$ of recommended dose of $\mathrm{N}$

$\mathrm{N}_{2}=100 \%$ of recommended dose of $\mathrm{N}$

$\mathrm{N}_{3}=25 \%$ higher than recommended dose of $\mathrm{N}$

recommended level of $\mathrm{N}$ applied at transplanting stage. In general finding, at 60 DAT the tallest plant was observed $(79.53 \mathrm{~cm})$ where $\mathrm{N}$ was applied at maximum tillering stage with $100 \%$ of recommended level of nitrogen. At 75 DAT, the tallest plant was 
observed $(110.22 \mathrm{~cm})$ when $\mathrm{N}$ applied at panicle initiation stage with $25 \%$ higher than of recommended level of $\mathrm{N}$ (Table 2). Plant height gradually increased at different DAT as a normal phenomenon. Reddy et al. (1988) reported that 120 $\mathrm{kg} \mathrm{N} \mathrm{ha}{ }^{-1}$ applied in three split dressing at transplanting (50\%), tillering $(25 \%)$ and panicle initiation stage $(25 \%)$ gave higher plant height than the same amount of $\mathrm{N}$ when applied in tow equal split dressing at transplanting and tillering or in a single dressing at transplanting.

\section{Number of total tiller hill ${ }^{1}$}

Total tillers hill $^{-1}$ was also significantly affected by both the nitrogen application at different growth stage and the amount of nitrogen applied at all dates of sampling. At 45 DAT, the highest tillers hill ${ }^{-1}(14.85)$ was found when $\mathrm{N}$ was applied at transplanting stage. At 60 DAT and 75 DAT, The highest tillers hill ${ }^{-1}$ were observed (11.82) when $\mathrm{N}$ applied at maximum tillering and panicle initiation stage respectively. Total tillers hill ${ }^{-1}$ gradually decreased first reached at a peak and there after it with advancement of age after 40 DAT. At all the DAT (45, 60 and 75), total tillers hill ${ }^{-1}$ was found 15.31, 11.81 and 9.37 respectively in $25 \%$ higher $\mathrm{N}$ level than recommended dose (Table 1).

In general, the increasing trend of total tillers hill $^{-1}$ was observed up to 45 and than declined up to 75 DAT. Singh and Singh (2002) reported that increasing levels of nitrogen significantly increased total tiller hill ${ }^{-1}$ up to a certain stage. Interaction effect of $\mathrm{N}$ application of different growth stages and different levels of $\mathrm{N}$ were not significantly affected by total tillers hill ${ }^{-1}$ for all sampling dates (Table 2).

\section{Number of leaf hill ${ }^{1}$}

Leaf number hill $^{-1}$ was significantly affected by both the nitrogen application at different growth stage and the amount of nitrogen applied at all dates of sampling. Number of leaf hill ${ }^{-1}$ was significantly increased with the advancement of growth stage. At 45, 60 and 75 DAT, the highest number of leaf hill ${ }^{-1}$ was obtained $63.65,64.00$ and 58.06 when $\mathrm{N}$ was applied at transplanting, maximum tillering and panicle initiation stage respectively. A decreasing trend was observed on leaf number hill $^{-1}$ after 60 DAT (Table 1). At 45, 60 and 75 DAT, the highest number of leaf hill $^{-1}$ was found 82.12, 62.98 and 64.55 respectively from $25 \%$ higher $\mathrm{N}$ level than recommended dose (Table 1). A decreasing trend of leaf number hill $^{-1}$ was observed after 45 up to 75 DAT (Table 1). Hossain et al. (1995) noticed for all nitrogen levels in general increased leaf number hill ${ }^{-}$ ${ }^{1}$ until the following stage and it declined there after till harvesting possibly due to leaf senescence. Interaction effect of $\mathrm{N}$ application of different growth stages and different levels of $\mathrm{N}$ was not significantly affected by leaf number hill ${ }^{-1}$ at all the sampling dates (Table 2).

Table 2. Interaction effect of $\mathrm{N}$ application stage and $\mathrm{N}$ levels on different plant characters at different days after transplanting (DAT)

\begin{tabular}{|c|c|c|c|c|c|c|c|c|c|}
\hline \multirow[b]{2}{*}{ Treatment } & \multicolumn{3}{|c|}{ Plant height $(\mathrm{cm})$} & \multicolumn{3}{|c|}{ No. of total tiller hill ${ }^{-1}$} & \multicolumn{3}{|c|}{ No. of leaf hill ${ }^{-1}$} \\
\hline & 45 DAT & 60DAT & 75DAT & 45DAT & 60DAT & 75DAT & 45DAT & 60DAT & 75DAT \\
\hline $\mathrm{T}_{1} \mathrm{~N}_{1}$ & $54.95 \mathrm{~cd}$ & 74.82 & 79.50 & 13.02 & 8.74 & 6.22 & 8.25 & 55.72 & 38.20 \\
\hline $\mathrm{T}_{1} \mathrm{~N}_{2}$ & $58.22 \mathrm{bc}$ & 77.44 & 87.91 & 14.97 & 10.72 & 7.28 & 83.77 & 56.57 & 47.45 \\
\hline $\mathrm{T}_{1} \mathrm{~N}_{3}$ & $64.95 \mathrm{a}$ & 81.95 & 103.68 & 16.55 & 11.79 & 8.90 & 84.92 & 59.85 & 60.52 \\
\hline $\mathrm{T}_{2} \mathrm{~N}_{1}$ & $51.20 \mathrm{~d}$ & 76.07 & 88.84 & 11.95 & 9.90 & 7.05 & 76.92 & 61.07 & 45.00 \\
\hline $\mathrm{T}_{2} \mathrm{~N}_{2}$ & $56.72 \mathrm{bcd}$ & 79.53 & 96.50 & 13.27 & 12.27 & 8.40 & 81.32 & 63.80 & 56.50 \\
\hline $\mathrm{T}_{2} \mathrm{~N}_{3}$ & $58.80 \mathrm{bc}$ & 85.01 & 107.98 & 15.45 & 13.31 & 9.08 & 82.97 & 67.15 & 64.70 \\
\hline $\mathrm{T}_{3} \mathrm{~N}_{1}$ & $40.55 \mathrm{e}$ & 66.48 & 97.71 & 10.52 & 7.20 & 7.80 & 73.15 & 46.97 & 44.62 \\
\hline $\mathrm{T}_{3} \mathrm{~N}_{2}$ & $53.10 \mathrm{~cd}$ & 75.08 & 99.97 & 11.97 & 8.77 & 9.12 & 76.00 & 55.22 & 61.15 \\
\hline $\mathrm{T}_{3} \mathrm{~N}_{3}$ & $61.12 \mathrm{ab}$ & 84.48 & 110.22 & 13.95 & 10.54 & 10.13 & 78.47 & 61.95 & 68.42 \\
\hline $\begin{array}{c}\text { Level of } \\
\text { significance }\end{array}$ & $*$ & NS & NS & NS & NS & NS & NS & NS & NS \\
\hline $\mathrm{CV}(\%)$ & 6.32 & 4.54 & 6.49 & 5.24 & 7.15 & 7.78 & 3.20 & 6.46 & 7.64 \\
\hline
\end{tabular}

In a column figurers with same letter or with out letters do not differ significantly at the level of 5\% as per DMRT.

NS = Not significant,$\quad *=5 \%$ level of significant.

$\mathrm{T}_{1}=$ Transplanting stage

$\mathrm{T}_{2}=$ Maximum tillering stage

$\mathrm{T}_{3}=$ Panicle initiation stage

$\mathrm{N}_{1}=50 \%$ of recommended dose of $\mathrm{N}$,

$\mathrm{N}_{2}=100 \%$ of recommended dose of $\mathrm{N}$ and

$\mathrm{N}_{3}=25 \%$ higher than recommended dose of $\mathrm{N}$ 


\section{Total dry matter production}

Total dry matter production was significantly influenced by both the nitrogen application at different growth stage and the amount of nitrogen applied at all dates of sampling. At 45, 60 and 75 DAT, the highest TDM was obtained $30.75,40.02$ and $49.23 \mathrm{gm} \mathrm{hill}{ }^{-1}$ when $\mathrm{N}$ was applied at transplanting, maximum tillering and panicle initiation stage respectively. At 45, 60 and 75 DAT, the highest TDM was found $30.71,39.60$ and 49.16 gm hill ${ }^{-1}$ respectively from $25 \%$ higher $\mathrm{N}$ level than

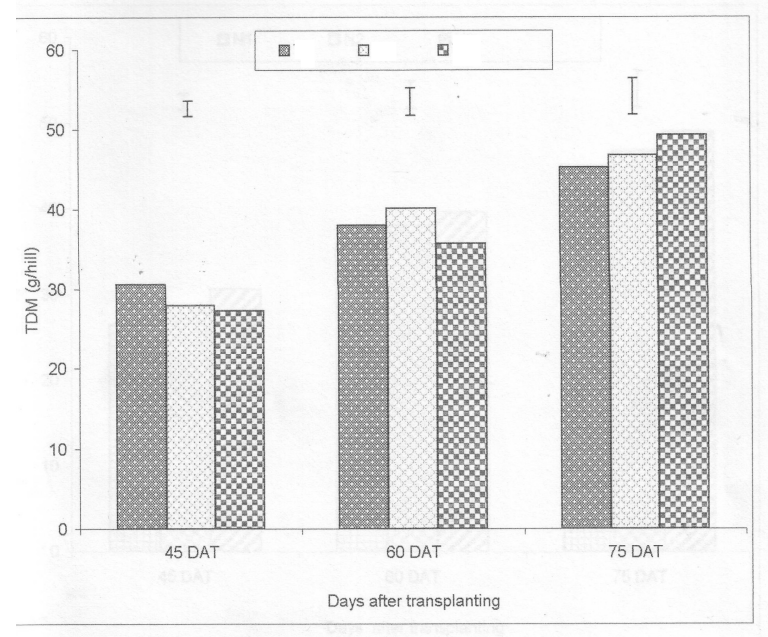

Fig. 1 Effect of $\mathrm{N}$ application stage on TDM production at different days after transplanting. Vertical bars represent $\mathrm{LSD}_{0.05}$ recommended dose. An increasing trend was observed on TDM up to 45-75 DAT by both the nitrogen application at different growth stage and the amount of nitrogen applied at all dates of sampling (Figure 1 and 2). Chowdhury et al. (1994) noticed the same that the dry matter yield increased due to nitrogen applied at active tillering and panicle initiation stages. Interaction effect of $\mathrm{N}$ application of different growth stages and different levels of $\mathrm{N}$ were not significantly affected by total dry matter gm hill $^{-1}$ at all the sampling dates (Fig. 3)

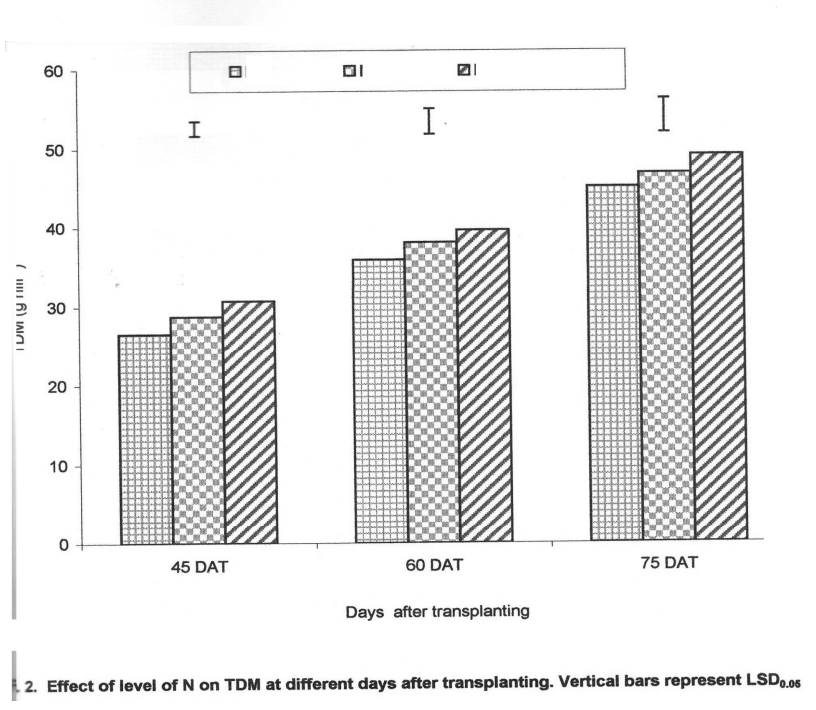

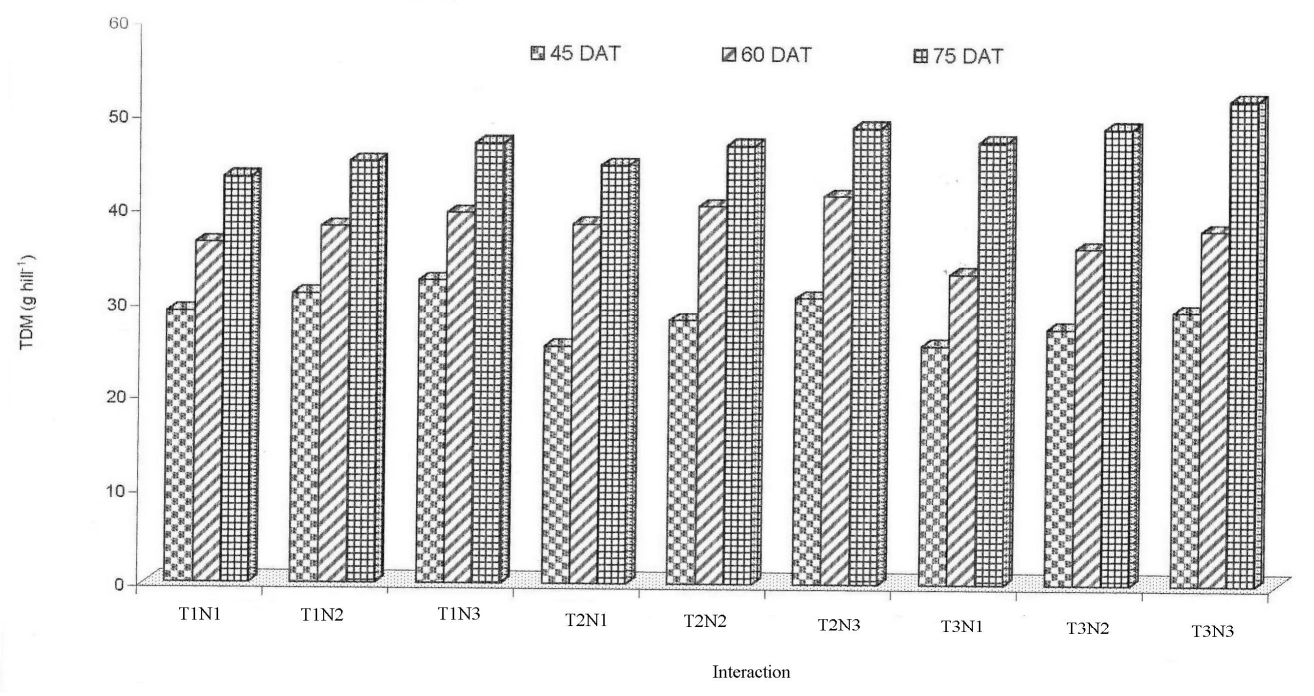

Fig. 3 Interaction effect of $\mathrm{N}$ application stage and $\mathrm{N}$ levels on TDM production at different days after transplanting 


\section{References}

BRRI. 1981. Annual Report. Bangladesh Rice Research Institute. Joydebpur, Gazipur. pp. 11-12.

BRRI. 1990. Annual Report. Bangladesh Rice Research Institute. Joydebpur, Gazipur. pp. 95-99.

Chowdhury, E.H., Hassan, G., Gill, K.H. and Sheikh, A.A. 1994. Increasing efficiency of nitrogen in rice through split application. Int. Rice Res. Notes. 19(2): 21 .

Dutta, R.K., Lahiri, B.P. and Mia, M.A.D. 1998. Characterization of some aromatic fine rice cultivars in relation to their physiochemical quality of grains. Indian Plant Phyiol. 3(1): 61-64.

FRG (Fertilizer Recommendation Guide). 2005. Published By Bangladesh Agricultural Research Council. Farmgate, New Airport Road, Dhaka1215.

Gomez, K.A. and Gomez, A.A. 1984. Statistical procedure Agricultural Research $\left(2^{\text {nd }}\right.$ edn). John Willy and Sons. New York. 680p.

Hossain, M.A., Salahuddin, A.B.M., Roy, K., Nasreen, S. and Ali, M.A. 1995. Effect of green manuring on the growth and yield of transplant aman rice. Bangladesh J. Agril. Sci. 22(1):21-29.
Lawal, M.I. and Lawal, A.B. 2002. Influence of N rate and placement method on growth and yield of rice at Kadawa, Nigeria. Crop Res. Hisar. 23(3): 403-411.

Nasreen, M. 2004. Disaster research: exploring the sociological approach to disaster in Bangladesh. Bangladesh e-Journal of Sociology, 1(2).

Reddy, J.V., Singh, J.N. and Verma, A.K. 1988. Effect of time of nitrogen on growth and yield of rice. Agril. Sci, Digest, India. 5(2):83-85.

Singh, C.S. and Singh, U.N. 2002. Effect of N and S nutrition on growth and yield of rice cultivars. Res. Crops. 3(3): 643-645.

Uddin, M.H. 2003. Effect of plant spacing and nitrogen level on yield of transplant aman rice cv.BRRIdhan39. A M.S thesis. Dept. of Agronomy, Bangladesh Agricultural University, Mymensingh, Bangladesh. 44p.

Uddin, M.J. 2004. Floods and Control Strategies in Bangladesh, The monthly Professors Current Affairs, September, 2004. pp.70-72. 